\title{
Air Pollution by Gases and PM in Rural Areas
}

\author{
D. Jandačka*, D. Ďurčanská \\ University of Zilina, Faculty of Civil Engineering, Department of Highway Engineering, \\ Univerzitna 8215/1, Zilina \\ *Corresponding author: dusan.jandacka@fstav.uniza.sk
}

DOI: $10.2478 /$ trans-2014-0012

\begin{abstract}
Pollution of the air by gases (nitric oxide, nitrogen dioxide, nitrogen oxides) and particulate matter is a matter of everyday life. Particulate matter (PM) is one of hazardous pollutants causing deterioration of the environment and thus quality of life of the population. Long-term exposure to effects of increased concentrations of gaseous pollutants can also cause deterioration of the environment and human health. Particulate matter and gases production by road transport is a burning issue, particularly for larger urban areas. However, pollution also occurs outside urban areas from different sources (road transport) that primarily affect vegetation and animals living in the given areas. The environment in urban areas can be affected secondarily by a long-range transfer of pollutants. Due to the dominant use of combustion engines, exhaust gases contain large amounts of gaseous pollutants as well as particulate matter. They particularly include a large amount of the finest PM fractions, which can remain in the air for a long time, easily enter respiratory tracks, and damage human health. The other part includes particulate matter produced by the friction of different parts of roads and vehicle fleets, which concerns matter of larger aerodynamic diameters. The aim of the presented part of the work is to monitor production of particulate matter and gaseous pollutants along roads in rural areas and evaluate their inter-relations, while taking into account the monitored meteorological characteristics and traffic volume.
\end{abstract}

KEY WORDS: Particulate matter, gaseous pollutants, meteorological characteristics, traffic volume, regression analysis.

\section{NEGATIVE EFFECTS OF SELECTED POLLUTANTS ON THE ENVIRONMENT}

Particulate matter (PM) can be produced by natural sources or by anthropogenic sources. The natural sources include sea salt, Earth's crust dust, pollen, and volcanic ash. The anthropogenic sources mainly include burning fuel in thermal power plants, local heating of households, and burning fuel in vehicles. Some of the major sources in urban areas include exhaust gas emissions, resuspension of road dust, and heating of households by wood or coal. These are the sources with low input of emissions to the air, under $20 \mathrm{~m}$, which leads to a significant impact on the level of concentration in the human breathing zone (Jandačka, 2013; Huzlík et al., 2011; Pant \& Harrison, 2013; Thorpe \& Harrison, 2008; Vojtěšek et al., 2009).

The effects of PM on human health are caused after its inhalation and penetration to the lungs and the blood circulatory system, which leads to adverse effects to respiratory, cardiovascular, immunity and neural systems. The ultrafine particles (with diameters $<0.1$ micrometre) can even 
reach the brain through the nose (Breysse et al., 2013). The chemical and physical interaction between PM and lung tissue may cause irritation or damage. The smaller the particle, the deeper they reach in the lungs. The impact of PM on mortality rate is clearly related to the fraction $\mathrm{PM}_{2.5}$, which makes $40-80 \%$ of weight concentration of $\mathrm{PM}_{10}$ in the ambient air in Europe (European Environment Agency, 2013; Jandačka, 2013). In addition, the "coarser" fraction 2.5-10 $\mu \mathrm{m}$ of the fraction $\mathrm{PM}_{10}$ has impact on human health and influences mortality rate.

Most of urban and rural inhabitants have experience with everyday exposure to increased concentrations of PM, which may have adverse effects on human health. Chronic exposure to PM contributes to the risk of cardiovascular diseases, respiratory track diseases, and lung cancer. The mortality rate related to air pollution is by $15-20 \%$ higher in urban areas with a high level of pollution in comparison with relatively cleaner areas. It is estimated that the average life expectancy in the European Union is shorter by 8.6 months due to the exposure to $\mathrm{PM}_{2.5}$. Apart from the effects on human health, PM may also have a negative impact on climate changes and ecosystems. In addition, PM contributes to soiling of buildings and may even have corrosive effects on buildings and structures, depending on PM composition (European Environment Agency, 2013).

Nitrogen dioxide is a reactive gas which is mainly formed by oxidation of nitrogen monoxide (NO). The high temperature combustion processes (e.g. processes in car engines and power plants) are the main sources of $\mathrm{NO}$ and $\mathrm{NO}_{2}$. These two gases are commonly known as $\mathrm{NO}_{\mathrm{x}}$. Nitrogen monoxide accounts for the major part $\mathrm{NO}_{\mathrm{x}}$ emissions. A small part of $\mathrm{NO}_{\mathrm{x}}$ emissions is directly emitted as $\mathrm{NO}_{2}$, usually $5-10 \%$ for the majority of combustion sources. Vehicles burning diesel are an exception. They usually produce higher proportions of $\mathrm{NO}_{2}$, up to $70 \% \mathrm{NO}_{\mathrm{x}}$ is $\mathrm{NO}_{2}$, since their exhaust treatment systems increase the direct emission of $\mathrm{NO}_{2}$ (Grice et al., 2009). There are clear signs that direct transport emissions of $\mathrm{NO}_{2}$ increase dramatically as a result of the higher number of diesel vehicles, particularly new vehicles with diesel engines (Euro 4 and 5). This may lead to more frequent breaches of the limit values of $\mathrm{NO}_{2}$ in peak hours.

Similarly to ozone, $\mathrm{NO}_{2}$ is also one of the air pollutants which primarily affects the respiratory system. Short-term exposure to $\mathrm{NO}_{2}$ may have adverse effects on human health, such as reduced function of the lungs for a sensitive part of the population, while long-term exposure may lead to adverse effects, such as higher vulnerability to respiratory system infections (Figure 1).

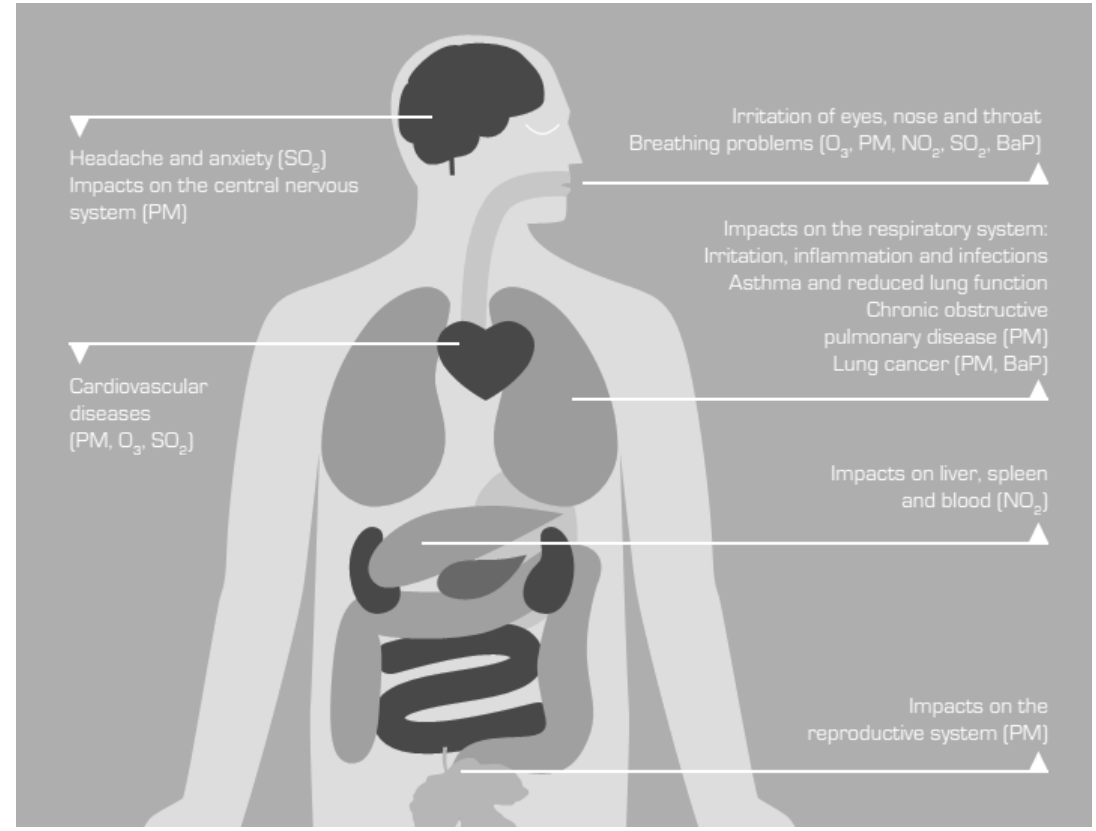

Figure 1: Impact of air pollution on human health (Breysse et al., 2013). 
$\mathrm{NO}_{2}$ is one of the reactive nitrogen compounds which may have undesirable effects on ecosystems, such as the acidifying effect. However, it is also a source of important nutrients. The excess of reactive nitrogen deposition may lead to the surplus of nitrogen nutrients in terrestrial and aquatic ecosystems, which causes eutrophication (nutrient oversupply). The excess of nitrogen may lead to changes in unique terrestrial and aquatic animal and plant communities and may cause a loss of biodiversity. Nitrogen oxides $\left(\mathrm{NO}_{\mathrm{x}}\right)$ play an important role in the formation of $\mathrm{O}_{3}$. They also contribute to the formation of secondary inorganic aerosols (SIAs) through the formation of nitrates thus contributing to the concentrations of $\mathrm{PM}_{10}$ and $\mathrm{PM}_{2.5}$ (European Environment Agency, 2013; Jandačka, 2013).

\section{MEASURING OF SELECTED POLLUTANTS}

The measurements of selected pollutants $\left(\mathrm{NO}, \mathrm{NO}_{2}, \mathrm{NO}_{\mathrm{x}}, \mathrm{PM}_{10}\right)$ were performed at motorway D1 between Považská Bystrica and Žilina near the village of Predmier. The measuring devices were placed in the premises of the former Centre of Administration and Maintenance of Motorways (SSÚD). The measuring station at the former SSÚD is located approx. $500 \mathrm{~m}$ from the village of Predmier, which lies on the left bank of the river Váh in the middle of the Bytča basin. At the northwest it is enclosed by the Javorníky Mountains and at the southeast by the Strážovská hornatina. The motorway D1 runs through the valley of the river Váh and is oriented in the direction southwest $\leftrightarrow$ northeast. The orientation of the valley implies the prevailing direction of winds, which blow predominantly from the southwest or the northeast (Figure 2).

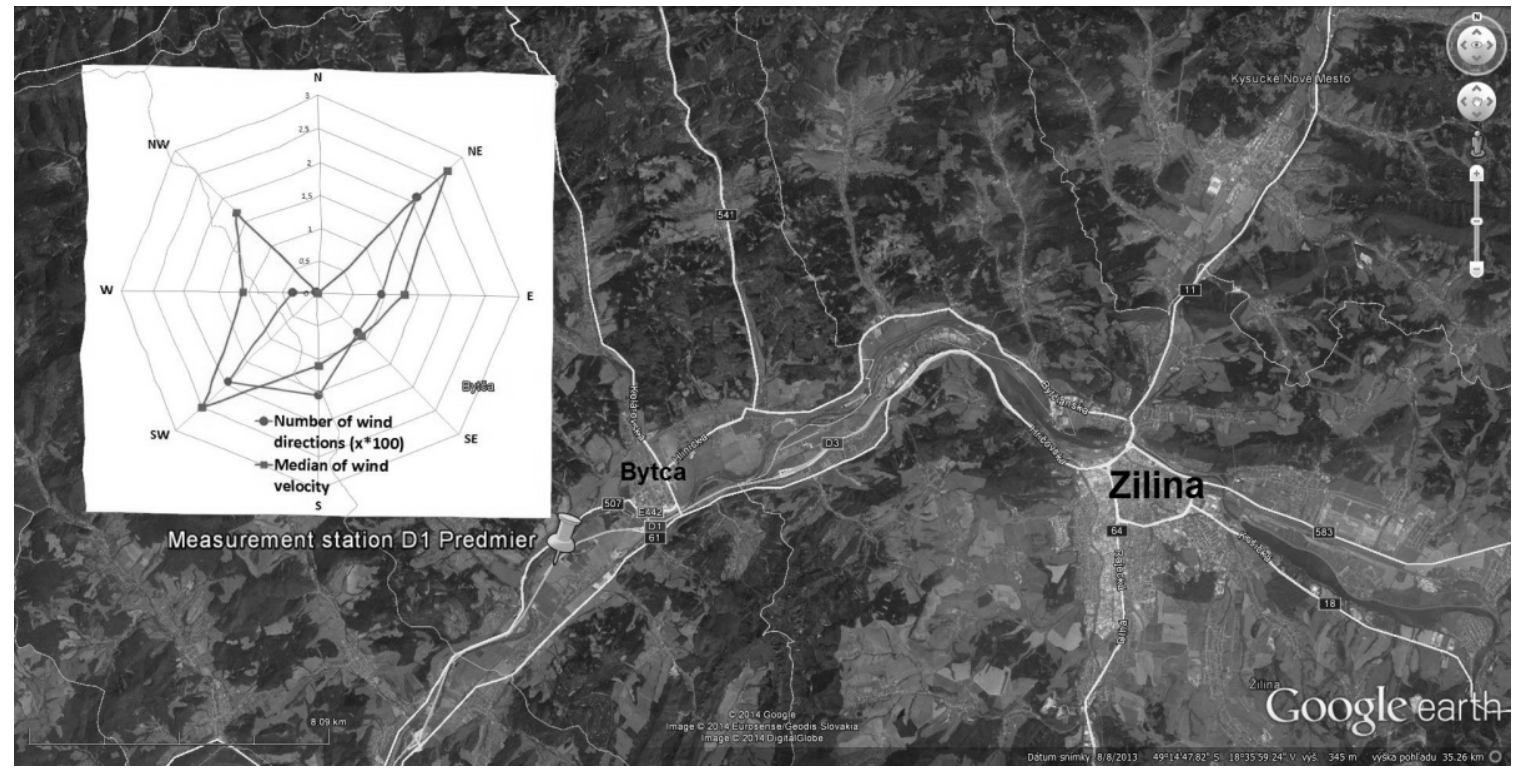

Figure 2: Measuring station and compass rose (source materials: Google Earth).

The measuring devices were placed approx. $7 \mathrm{~m}$ from the edge of the sealed part of the road. Different equipment (Figure 3) was used for the measurements. This article evaluates the data from the mobile monitoring station of air quality of the University of Žilina. The measured pollutants by the mobile monitoring stations included $\mathrm{NO}, \mathrm{NO}_{2}, \mathrm{NO}_{\mathrm{x}}, \mathrm{PM}, \mathrm{CO}, \mathrm{SO}_{2}, \mathrm{O}_{3}$. The following part evaluates mostly the pollutants of $\mathrm{NO}, \mathrm{NO}_{2}, \mathrm{NO}_{\mathrm{x}}, \mathrm{PM}_{10}$, due to their potential origin from road traffic. The values of these pollutants were measured in May 2013, November 2013 and January 2014 (Figure 4). 

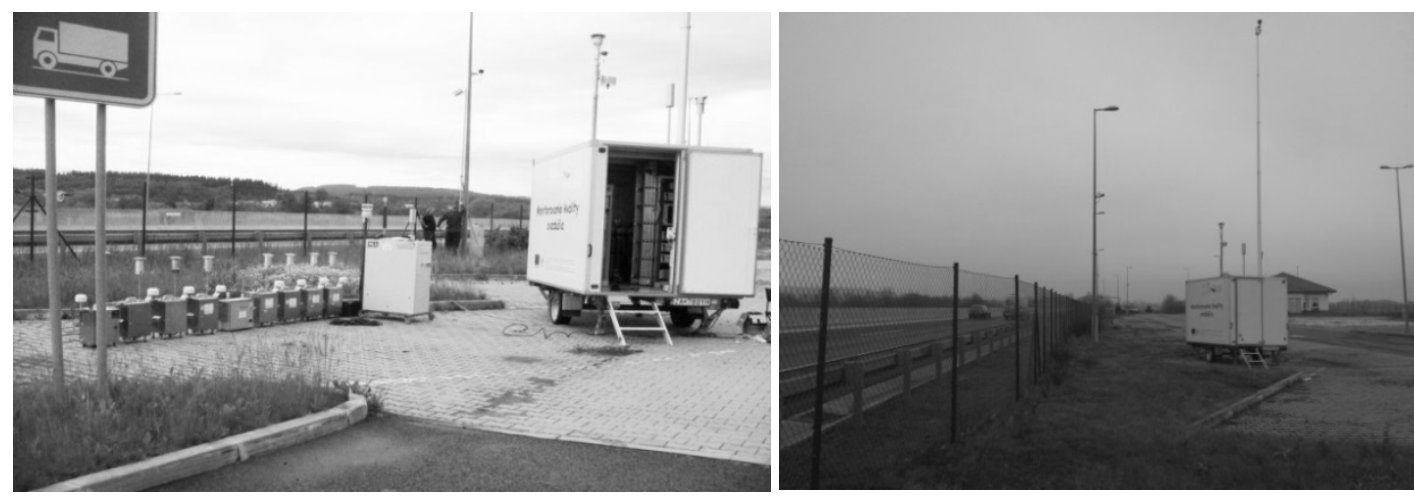

Figure 3: Deployment of measuring equipment while measuring air pollution.

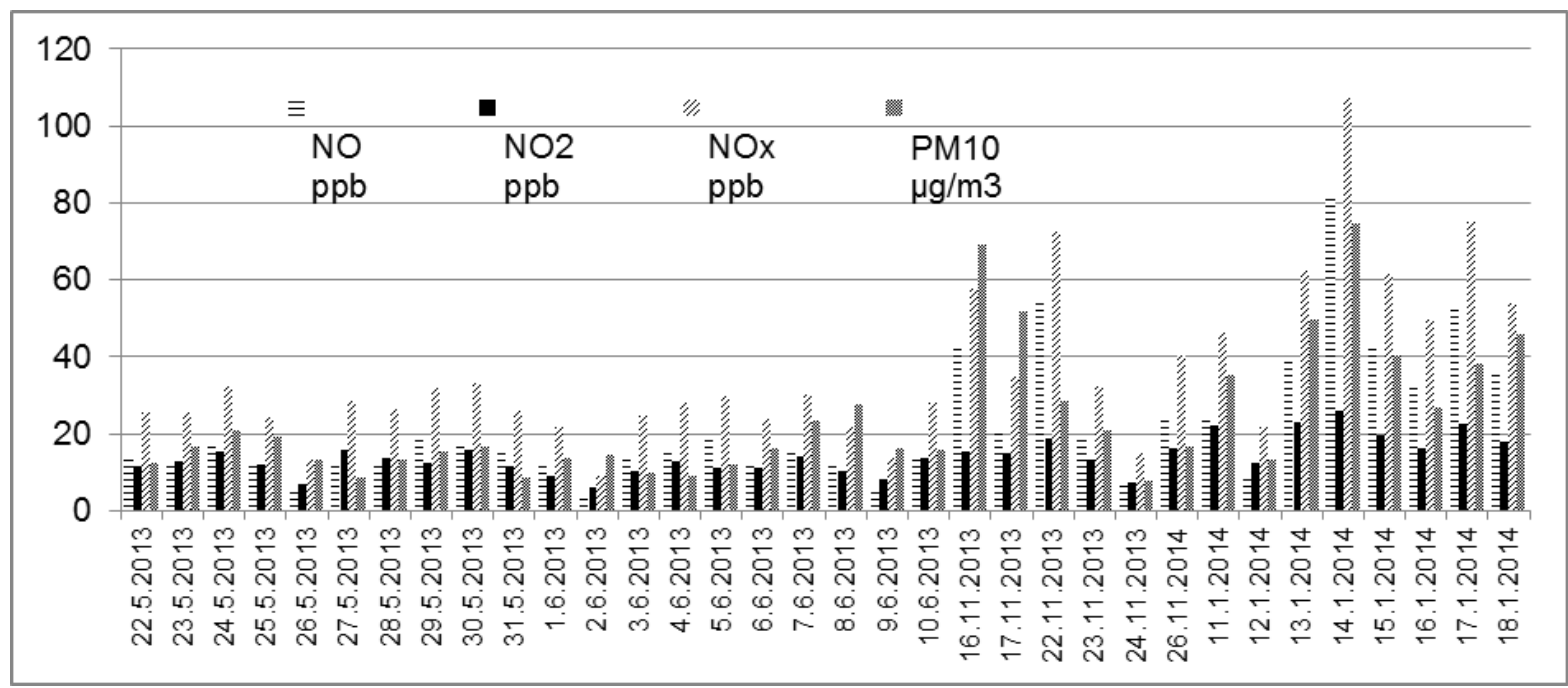

Figure 4: Average 24-hour concentrations of selected pollutants from performed measurements.

Together with the monitoring of air pollution, the meteorological parameters (temperature, humidity, speed and direction of wind) (Figure 5), and road traffic volume on motorway D1 were recorded (Figure 6).

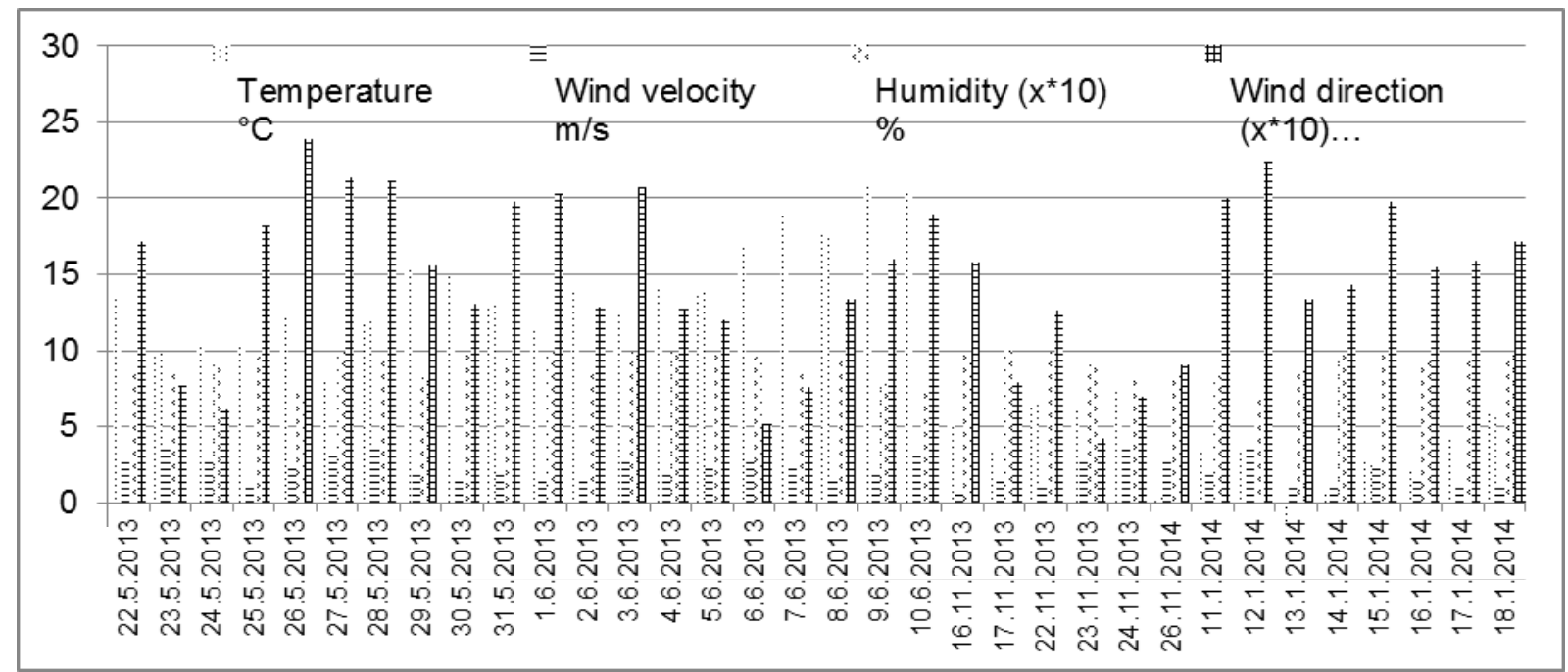

Figure 5: Average 24-hour values of meteorological parameters of selected pollutants from performed measurements. 


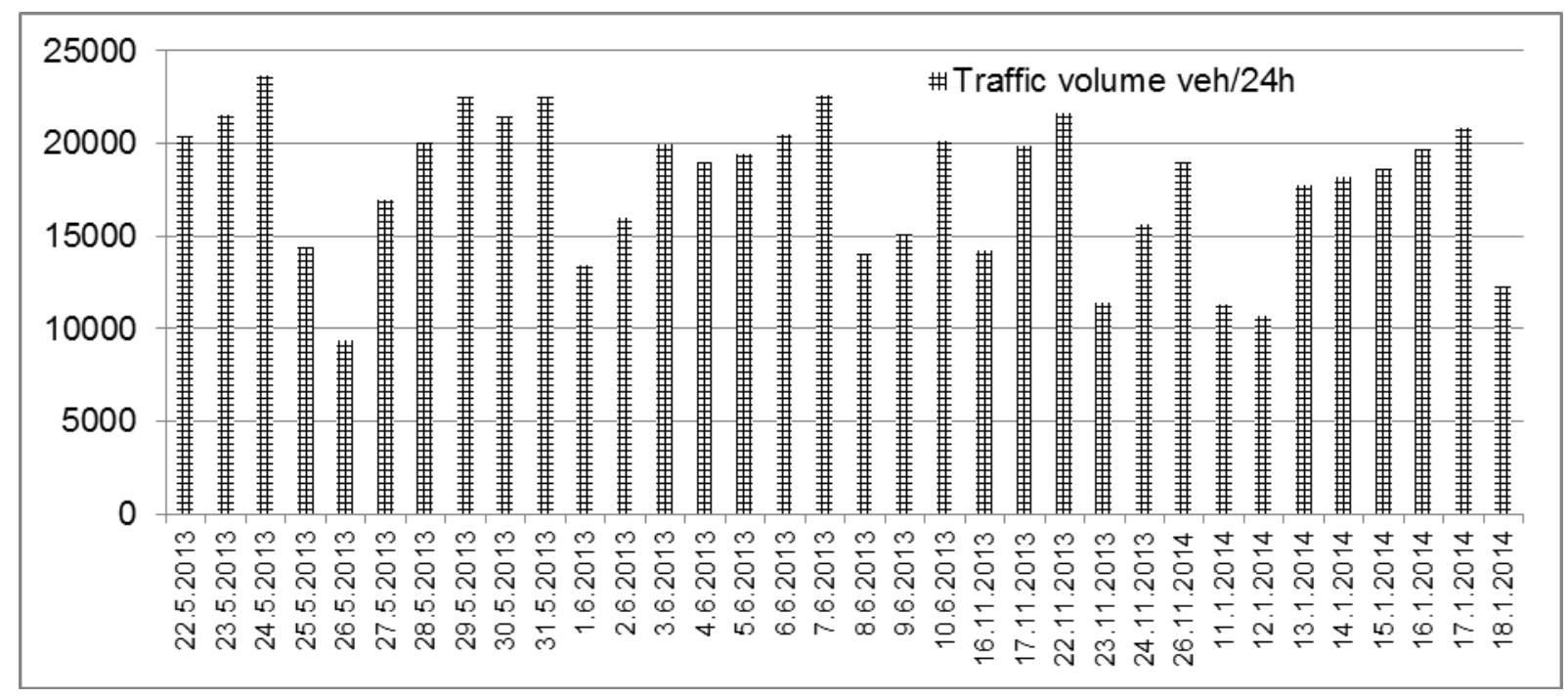

Figure 6: Average 24-hour traffic volumes of selected pollutants from performed measurements.

The wind direction in the given area is based on the surrounding terrain (flat terrain surrounded by a hilly relief forming the valley of the river Váh in direction southwest $\leftrightarrow$ northeast) (Figure 2). The prevailing winds blow in the direction of the valley of the river Váh; the motorway D1 is oriented in the same direction. This fact also implies the pollution mass flow produced by road traffic on D1, in the direction of the motorway orientation. The level of air pollution by road traffic along both sides of the motorway can be affected by the assumed propagation of imissions in the direction of the motorway. Despite this fact, we tried to create a model of relations of selected pollutants on the local conditions.

\section{EVALUATION OF AIR POLLUTION BY SELECTED POLLUTANTS}

A matrix of hourly concentrations of pollutants, meteorological parameters and traffic volumes was created in order to evaluate relationships between the selected air pollution components (NO, $\mathrm{NO}_{2}, \mathrm{NO}_{\mathrm{x}}, \mathrm{PM}_{10}$ ) and the ambient conditions (meteorological parameters). The matrix consisted of separately selected dependent variables $\left(\mathrm{NO}, \mathrm{NO}_{2}, \mathrm{NO}_{\mathrm{x}}, \mathrm{PM}_{10}\right)$ and independent variables (temperature (TEMP), humidity (HUMI), wind speed (WS), traffic volume (ID)) and contained 775 items (measured values). Multiple regression analysis (MRA) was used for the evaluation. Further evaluations deal with the inter-correlation of dependent variables $\mathrm{PM}_{10}$ and $\mathrm{NO}, \mathrm{NO}_{2}$ and $\mathrm{NO}_{\mathrm{x}}$.

MRA concerns the group of techniques used for studying a linear dependence between two or more variables. It determines estimates of $\beta$ parameters in a regression model

$y_{i}=\beta_{0}+\beta_{1} x_{i, 1}+\beta_{2} x_{i, 2}+\cdots+\beta_{m} x_{i, m}+\varepsilon_{i}$,

where $x$ are independent variables and $y$ is a dependent variable. Index $i$ stands for a serial measurement number, $\beta$ are unknown regression parameters and $b$ are their estimates of number $m$ (Table 1). The absolute member $\beta_{0}$ is the intersection point of the hyperplane with axis $y . \varepsilon_{i}$ are random errors. The estimates of parameters $b_{i}$ are the directions of the regression hyperplane from the direction $x_{i}$ and are called partial regression parameters (or partial regression coefficients for standardised variables) (Meloun \& Militký, 2006). 
Table 1: Significant included variables for models of $\mathbf{P M}_{10}, \mathbf{N O}_{\mathbf{x}}, \mathbf{N O}_{2}, \mathrm{NO}$ and results of MRA.

\begin{tabular}{|c|c|c|c|c|c|}
\hline $\begin{array}{l}\text { Dependent } \\
\text { variable }\end{array}$ & $\begin{array}{c}\text { Included } \\
\text { independent } \\
\text { variable }\end{array}$ & $\begin{array}{c}\text { Estimate of } \\
\text { parameter } \\
\text { “b” }\end{array}$ & $\begin{array}{c}\text { Significance } \\
\text { of “p”" }\end{array}$ & $\begin{array}{c}\text { Correlation } \\
\text { coefficient }\end{array}$ & $\begin{array}{l}\text { Coefficient of } \\
\text { determination } \\
\text { of multiple } \mathbf{R}^{2}\end{array}$ \\
\hline \multirow[t]{4}{*}{$\mathbf{P M}_{10}$} & Abs. member & 42.89 & 0.000000 & - & \multirow{4}{*}{0.32} \\
\hline & TEMP & -1.32 & 0.000000 & -0.49 & \\
\hline & WS & -4.41 & 0.000104 & -0.40 & \\
\hline & ID & 0.005 & 0.002683 & -0.14 & \\
\hline \multirow[t]{4}{*}{$\mathrm{NO}_{\mathrm{x}}$} & Abs. member & 51.71 & 0.000000 & & \multirow{4}{*}{0.48} \\
\hline & TEMP & -2.14 & 0.000000 & -0.48 & \\
\hline & WS & -7.53 & 0.000000 & -0.40 & \\
\hline & ID & 0.03 & 0.000000 & 0.17 & \\
\hline \multirow[t]{4}{*}{$\mathrm{NO}_{2}$} & Abs. member & 16.68 & 0.000000 & & \multirow{4}{*}{0.38} \\
\hline & TEMP & -0.50 & 0.000000 & -0.40 & \\
\hline & WS & -1.52 & 0.000000 & -0.30 & \\
\hline & ID & 0.008 & 0.000000 & 0.22 & \\
\hline \multirow[t]{4}{*}{ NO } & Abs. member & 35.03 & 0.000000 & & \multirow{4}{*}{0.45} \\
\hline & TEMP & -1.64 & 0.000000 & -0.47 & \\
\hline & WS & -6.01 & 0.000000 & -0.41 & \\
\hline & ID & 0.02 & 0.000000 & 0.14 & \\
\hline
\end{tabular}

Temperature (TEMP), wind speed (WS), and traffic volume (ID) (Table 1) were found as the significant variables from the meteorological parameters and traffic volume for all dependent variables of $\mathrm{PM}_{10}, \mathrm{NO}_{\mathrm{x}}, \mathrm{NO}_{2}$ and $\mathrm{NO}$. Humidity was not included in any model. Its high sensitiveness to the ambient air temperature was confirmed with $\mathrm{PM}_{10}$. The air temperature has a significant impact on the process of formation, changes and condition of particulate matter in the air. Wind speed mainly influences the dispersion of particulate matter and long distance transfer of pollution by particulate matter. Both factors, temperature and wind speed, show a negative correlation with the concentrations of $\mathrm{PM}_{10}$, which means that the concentrations of $\mathrm{PM}_{10}$ are higher under lower temperature and lower wind speed. Correlation coefficients $\mathrm{PM}_{10}$ vs. temperature -0.49 and $\mathrm{PM}_{10}$ vs. wind speed -0.40 are not relatively high, which may be caused by prevailing wind flow in the given area and by the fact that the monitoring station is hit by the pollutant mass flow only marginally. $\mathrm{PM}_{10}$ negatively correlates with traffic volume, which is a bit misleading since road traffic in the given location is considered the dominant source of pollution. However, the concentrations of $\mathrm{PM}_{10}$ are so much affected by the meteorological parameters that it is very difficult to prove the interconnection of road traffic and air pollution by particulate matter. The determination coefficient for the model with a dependent variable $\mathrm{PM}_{10}$ and independent variables temperature, wind speed, and traffic volume is just 0.32 . Therefore, it only characterizes $32 \%$ of the original data dispersion, which can be caused by the absenting main flow of pollution by road traffic.

Regarding the dependent variables $\mathrm{NO}_{x}, \mathrm{NO}_{2}, \mathrm{NO}$, the model characterized $48 \%, 38 \%$, $45 \%$ of the original data dispersion. The values are a bit higher for these gaseous components of air pollution than for particulate matter. The correlation between $\mathrm{NO}_{\mathrm{x}}, \mathrm{NO}_{2}, \mathrm{NO}$ and traffic volume was low $(0.17,0.22,0.14)$ and positive, which usually means positive interconnection of these gaseous pollutants and traffic volume, and possibly lower sensitiveness to meteorological parameters as well as to particulate matter. In addition, these gases can probably more easily propagate into the local environment out of the prevailing air flow. 

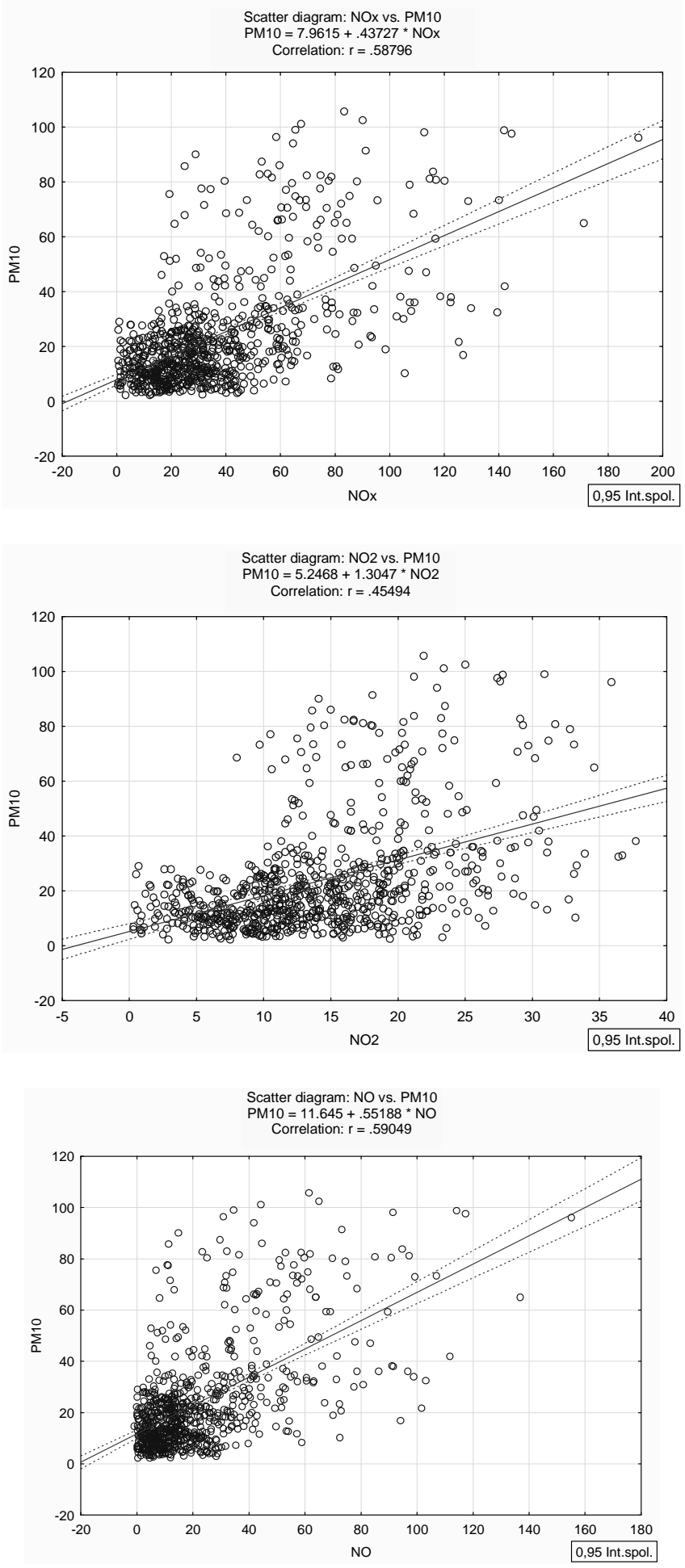

Figure 7: Correlation of $\mathrm{PM}_{10}$ and $\mathrm{NO}_{\mathrm{x}}, \mathrm{NO}_{2}, \mathrm{NO}$ and their relationships.

The inter-correlation of $\mathrm{PM}_{10}$ expressed by correlation coefficients and significant markers of road traffic of nitrogen oxides $\mathrm{NO}_{\mathrm{x}} \mathrm{r}=0.58, \mathrm{NO}_{2} \mathrm{r}=0.45$, NO $\mathrm{r}=0.59$ is relatively high (Figure 7). The analysis of the relationship of $\mathrm{PM}_{10}$ and $\mathrm{NO}$ shows that nearly $35 \%$ variability of both variables is determined together, thus they are probably interconnected with road traffic.

Regarding the proportion of individual components of $\mathrm{NO}_{\mathrm{x}}, \mathrm{NO}_{2}$ shows above average presence in the total air pollution by nitrogen oxides (Figure 8). This finding may lead 
to a theory on a large number of diesel vehicles in traffic flow and thus direct production of $\mathrm{NO}_{2}$ to the air (Grice et al., 2009). In addition, the theory may be supported by the oxidation of $\mathrm{NO}$ formed by burning fuel in vehicle engines to $\mathrm{NO}_{2}$ in the air.

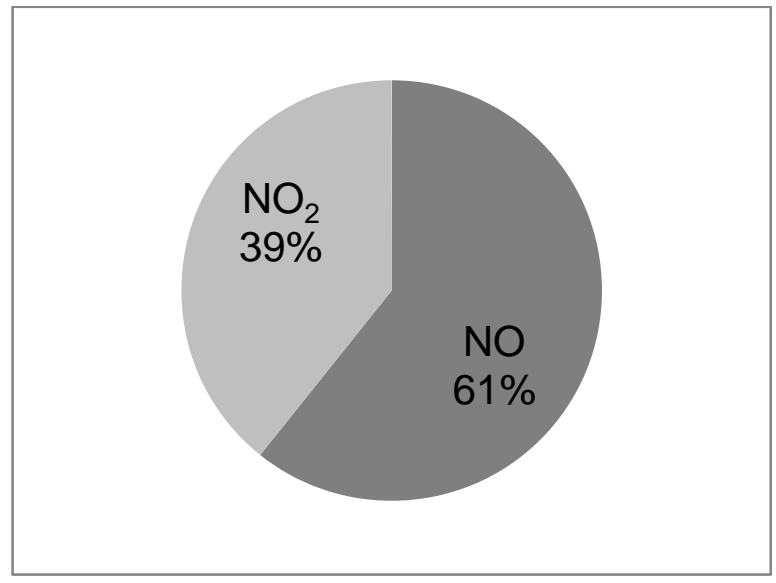

Figure 8: Proportion of $\mathrm{NO}_{2}$ and $\mathrm{NO}$ in $\mathrm{NO}_{\mathrm{x}}$.

\section{CONCLUSION}

Research of air pollution by road traffic is a complicated process particularly in terms of the direct relationship of measuring pollution and road traffic. The emissions produced by road traffic are influenced by many factors which have an impact on their propagation and on their secondary production. The dispersed emissions in the air (imissions) are mainly subordinate to the current local meteorological conditions. The measurements performed in a rural area at motorway D1 confirmed several assumptions related to the relationships of air pollutants and meteorological parameters. Temperature (TEMP) appeared to be the most influential parameter of concentrations of $\mathrm{PM}_{10}, \mathrm{NO}_{\mathrm{x}}, \mathrm{NO}_{2}$, and $\mathrm{NO}$. The correlation with temperature was negative for all four pollutants, i.e. the lower the temperature, the higher the concentration. The other significant variables for the model of concentrations of selected pollutants were wind speed and traffic volume. A high correlation of $\mathrm{PM}_{10}$ and nitrogen oxides was found, while their joint dispersion rate is $35 \%$. Their mutually explained proportion may indicate origin in road traffic, since road traffic is a significant producer of nitrogen oxides. The proportion of individual components of $\mathrm{NO}_{\mathrm{x}}$ is $39 \% \mathrm{NO}_{2}$ and $61 \%$ NO. The high presence of $\mathrm{NO}_{2}$ in $\mathrm{NO}_{\mathrm{x}}$ may be a result of a high proportion of diesel cars on motorway D1, however, it may also be related to the oxidation of $\mathrm{NO}$ to $\mathrm{NO}_{2}$ in the ambient air.

Behaviour and dispersion of pollutants in the air is largely influenced by the character of area, meteorological parameters, and the source of pollution itself. The measurement station was placed in a flat rural area (without any artificial obstacles). The prevailing winds flowed in the direction of motorway D1. The emissions produced by road traffic are influenced by these factors and their "travel" in the air is a result of a coaction of individual components of the environment, which is affected by the air pollution. 


\section{ACKNOWLEDGEMENT}

The paper originated thanks to being supported by means of a grant for the scientific research task VEGA 1/0508/2011 entitled Overall characteristics and chemical composition of particulates as created by the vehicular traffic.

\section{REFERENCES}

Breysse, P. N. et al., 2013. US EPA particulate matter research centers: summary of research results for 2005-2011. Air Quality, Atmosphere \& Health [online]. 6 (2), pp. 333-355 [cited 2014-07-29]. ISSN 1873-9326. Retrieved from: http://link.springer.com/article/10.1007\%2Fs11869-012-0181-8

European Environment Agency, 2013. Air quality in Europe - 2013 report [online]. Copenhagen (Denmark): EEA. 107 p. [cited 2014-07-29]. Retrieved from: http://www.eea.europa.eu/publications/air-quality-in-europe-2013

Grice, S. et al., 2009. Recent trends and projections of primary NO2 emissions in Europe. Atmospheric Environment [online]. 43 (13), pp. 2154-2167 [cited 2014-07-29]. ISSN 13522310. Retrieved from: http://www.sciencedirect.com/science/article/pii/S1352231009000508

Huzlík, J., Ličbinský, R., Mikuška, P. 2011. Identification of Re-suspended Particle Matter Particles Sources by Statistical Methods. In 12th Annual Conference of the Czech Aerosol Society: proceedings, Cejkovice (Czech Republic), pp. 69-74. ISBN 978-80-86186-31-3.

Jandačka, D., 2013. Vplyv cestnej dopravy na výskyt tuhých častíc [Road Transport Impact on the Occurrence of Particulates]. Dissertation thesis. University of Zilina. $134 \mathrm{p}$. (in Slovak)

Jandačka, D., Ďurčanská, D., 2014. Znečistenie ovzdušia plynnými látkami a tuhými časticami mimo zastavaného územia [Air Pollution by Gases and PM in Rural Areas]. In Jandová, V., Mikulová, I., Ličbinský, R. VI Czech and Slovak Conference "Transport, Health and the Environment", Brno (Czech Republic), November 10-11, 2014. Brno: Transport Research Centre, pp. 15-23. ISBN 978-80-86502-85-4. (in Slovak)

Meloun, M., Militký, J., 2006. Kompendium statistického zpracováni dat [Statistical Data Assessment Compendium]. Prague: Academia. 982 p. ISBN 80-200-1396-2. (in Czech)

Pant, P., Harrison, R. M., 2013. Estimation of the contribution of road traffic emissions to particulate matter concentrations from field measurements: A review. Atmospheric Environment [online]. 77, pp. 78-97 [cited 2014-02-21]. ISSN 1352-2310.

Retrieved from: http://www.sciencedirect.com/science/article/pii/S1352231013002732

Thorpe, A., Harrison, R. M., 2008. Sources and properties of non-exhaust particulate matter from road traffic: A review. Science of Total Environment [online]. 400 (1-3), pp. 270282 [cited 2014-02-21]. ISSN 0048-9697. Retrieved from: http://www.sciencedirect.com/science/article/pii/S004896970800658X 
Vojtěšek, M., Mikuška, P., Večeřa, Z., 2009. Výskyt, zdroje a stanovení kovů v ovzduší. [Occurence, sources and determination of metals in air]. Chemical Letters, 103, pp. 136144. ISSN 1213-7103. (in Czech)

NOTICE: The article was taken over from the proceedings of VI Czech and Slovak Conference "Transport, Health and the Environment" held on 10 - 11 November 2014 in Brno (Czech Republic), upon the decision of the proceedings publisher Transport Research Centre and with the consent of the authors of the article.

With the consent of the authors, the article was adapted on the basis of editing instructions of Transactions on Transport Sciences journal and translated into English language. 